\title{
Allergic Fungal Airway Disease
}

\author{
Rick EM, Woolnough K, Pashley $\mathrm{CH}$, Wardlaw AJ
}

Institute for Lung Health, Department of Infection, Immunity \& Inflammation, University of Leicester and Department of Respiratory Medicine, University Hospitals of Leicester NHS Trust, Leicester, UK

J Investig Allergol Clin Immunol 2016; Vol. 26(6): 344-354

doi: 10.18176/jiaci.0122

\begin{abstract}
Fungi are ubiquitous and form their own kingdom. Up to 80 genera of fungi have been linked to type I allergic disease, and yet, commercial reagents to test for sensitization are available for relatively few species. In terms of asthma, it is important to distinguish between species unable to grow at body temperature and those that can (thermotolerant) and thereby have the potential to colonize the respiratory tract. The former, which include the commonly studied Alternaria and Cladosporium genera, can act as aeroallergens whose clinical effects are predictably related to exposure levels. In contrast, thermotolerant species, which include fungi from the Candida, Aspergillus, and Penicillium genera, can cause a persistent allergenic stimulus independent of their airborne concentrations. Moreover, their ability to germinate in the airways provides a more diverse allergenic stimulus, and may result in noninvasive infection, which enhances inflammation. The close association between IgE sensitization to thermotolerant filamentous fungi and fixed airflow obstruction, bronchiectasis, and lung fibrosis suggests a much more tissue-damaging process than that seen with aeroallergens.

This review provides an overview of fungal allergens and the patterns of clinical disease associated with exposure. It clarifies the various terminologies associated with fungal allergy in asthma and makes the case for a new term (allergic fungal airway disease) to include all people with asthma at risk of developing lung damage as a result of their fungal allergy. Lastly, it discusses the management of fungirelated asthma.
\end{abstract}

Key words: Thermotolerant fungi. Allergic fungal airway disease (AFAD). ABPA. SAFS. Asthma. Allergic fungal rhinosinusitis (AFRS). Immune responses. Diagnosis. Treatment.

\section{Resumen}

Los hongos son obicuos y forman su propio reino. Hasta 80 géneros de hongos han sido asociados con la enfermedad alérgica tipo l; sin embargo, los reactivos comerciales para testar las sensibilizaciones a los mismos, se encuentran disponibles para un número relativamente pequeño de especies. En cuanto al asma, es importante distinguir entre especies incapaces de crecer en temperatura ambiente y aquellas que son termotolerantes y que, por lo tanto, tienen una capacidad potencial para colonizar el tracto respiratorio. Los primeros, que incluyen los géneros comúnmente estudiados Alternaria y Cladosporium, pueden actuar como aeroalérgenos y sus efectos clínicos están relacionados con los niveles de exposición. En contraste, las especies termotolerantes, que incluyen hongos del género Candida, Aspergillus y Penicillium, pueden causar un estímulo alergénico persistente independiente de su concentración en el aire. Además, su capacidad para germinar en las vías aéreas da lugar a estímulos alergénicos más diversos y puede dar como resultado infecciones no invasivas que facilitan la inflamación. La estrecha asociación entre sensibilización dependiente de IgE a hongos filamentosos termotolerantes y la obstrucción del flujo aéreo, bronquiectasias y fibrosis pulmonar sugiere que esto lleva a un proceso de daño tisular mucho mayor que el producido por aeroalérgenos. Esta revisión ofrece una visión general de los alérgenos de los hongos y los patrones de las enfermedades clínicas asociadas a su exposición. Trata de aclarar la terminología variada asociada con la alergia a hongos en asma, ofreciendo un nuevo término (enfermedad alérgica de las vías aéreas por hongos) para englobar a todos los pacientes asmáticos con riesgo de desarrollar daños pulmonares como resultados de su alergia a hongos. Por último, se discute el manejo del asma relacionada con hongos.

Palabras clave: Hongos termotolerantes. Enfermedad alérgica de las vías aéreas por hongos. Aspergillosis broncopulmonar alérgica. Asma severa con sensibilización a hongos. Asma. Rhinosinusitis por alergia a hongos. Respuesta immune. Diagnóstico. Tratamiento. 


\section{Introduction}

Fungi are eukaryotes that form their own kingdom. Around 100000 fungal species have been named [1], although there are estimated to be from 1.5 to 3 million species worldwide $[2,3]$. According to the Assembling the Fungal Tree of Life (AFTOL) project, the fungal kingdom can be divided into as many as 8-10 phyla. Among these, the Ascomycota and Basidiomycota groups together form the Dikarya, which represent approximately $98 \%$ of described fungal species [4]. These ubiquitous organisms have adapted to a variety of ecological habitats. They are involved in the degradation of decomposing organic matter in nature [5], but are also used in industry, for example in the production of food, antibiotics, and enzymes [6].

Most fungi, such as the plant pathogens Cladosporium and Alternaria species, are mesophilic, growing at an optimum temperature of $18^{\circ} \mathrm{C}$ to $22^{\circ} \mathrm{C}$. They rarely cause infection but can be encountered as allergens. Thermotolerant fungi are able to grow in the environment and at body temperature and are therefore capable of acting as allergens, commensals, and opportunistic pathogens [7]. Fungal pathogens have evolved independently and repeatedly throughout the kingdom [8]. They can damage their host through infection, ranging from superficial cutaneous infections to life-threatening invasive mycoses, by producing toxins, or by inducing allergic reactions [9]. The few species that have been detected in the upper and lower respiratory airways $[10,11]$ include yeasts, particularly Candida species, Penicillium, and Aspergillus species, with the latter constituting the most prominent cause of fungal lung infections.

The incidence of allergic disease, which affects around 1 in 3 people in the UK [12], has increased in developed societies over the last 50 years and now represents a considerable challenge to the healthcare industry [13]. Everybody inhales a complex mixture of hyphal fragments, fungal spores, and yeasts daily [14]. The species' composition varies depending on the day and season, with the highest concentrations in late summer and early autumn, when $>50000$ fungal spores per cubic meter of air per day can be present [14]. Spores frequently exceed the concentration of pollen grains by 100 to 1000-fold [9]. Frequency also varies between the outdoor and indoor environment, with the indoor fungal spore concentration comprising around $16 \%$ of the outdoor concentration in noncontaminated housing [15]. The majority of airborne spores are produced by members of the Ascomycota and Basidiomycota, with asexually produced conidia comprising $30 \%$ to $60 \%$ of total airborne spores [9]. Larger spores $(>10 \mu \mathrm{m})$ are usually deposited in the nasopharynx and associated with hay fever symptoms, although most are smaller, ranging from $2 \mu \mathrm{m}$ to $10 \mu \mathrm{m}$, including those from Aspergillus and Penicillium species $[9,16]$. Small spores and fragments of larger spores can reach the lower airways $[9,17]$. The quantity of fragments of some fungi can exceed their respective number of spores [18,19].

Both the upper and lower airways try to remove fungi by mechanical means such as sinus turbulence or the mucociliary escalator and by immunological means such as engulfment and digestion by alveolar phagocytes. The immune response thereby represents a balance between pro-inflammatory reduction of fungal burden and anti-inflammatory reduction of host tissue damage [20]. Most fungal allergens are released after spores germinate [21], as the spores are covered by a protective hydrophobin layer that enables evasion of the immune system [22]. Symptoms triggered by fungal allergens range from rhinitis to allergic bronchopulmonary aspergillosis (ABPA), a complication that usually accompanies other lung diseases such as asthma. Thermotolerant fungi play a special role, as they are able to colonize the lower airways, thereby representing a persistent allergen source.

Although the importance of sensitization to fungi in human health has been evaluated, its contribution to allergic airway diseases remains largely understudied $[23,24]$.

\section{Allergic Immune Responses to Fungi}

The defence against pathogens in humans is based on a combination of innate and adaptive immune responses. Traditionally, the latter discriminates between type 1 helper $\mathrm{T}$ cell $\left(T_{H}\right), T_{H} 2, T_{H} 17$, and regulatory T-cell responses, which are dependent on the pathogens and cytokines involved. $\mathrm{T}_{\mathrm{H}} 2$ responses are usually directed against parasites, whilst the antifungal response is predominantly mediated by $T_{H} 1$ and $T_{H} 17$ cells [25]. Allergic reactions represent a deranged $T_{H} 2$ immune response against normally harmless molecules [26] that is commonly associated with the production of allergenspecific IgE antibodies. This humoral type I immune response represents 1 of 4 classified hypersensitivity responses [27]. $\operatorname{IgE}$ antibodies are produced after the first contact with the allergen, which leads to an asymptomatic stage called atopy. After re-exposure to the allergenic source, allergen-specific $\mathrm{IgE}$ antibodies bound to high-affinity receptor FceRI of innate effector cells such as basophils and mast cells are crosslinked, leading to the immediate release of anaphylactogenic mediators [26] and peripheral blood eosinophilia [28]. These cells reside mostly near skin and mucosal surfaces such as the respiratory and gastrointestinal tracts, where the subsequent allergic reactions occur. The reactions can manifest as IgE-associated atopic dermatitis [29], allergic rhinitis or rhinosinusitis, allergic asthma, and food allergy [23]. A sensitized individual does not have to experience symptoms, which may depend on the level of exposure and other contributing factors during exposure, such as the individuals' health condition and their immune system [30,31].

Type I hypersensitivity reactions have been observed to about 80 fungi, predominantly to species from the Ascomycota [24]. The prevalence of sensitization to fungi is unclear, although estimates suggest that $3 \%$ to $10 \%$ of the general population, $12 \%$ to $42 \%$ of atopic patients, and up to $66 \%$ of patients with severe asthma may be sensitized to fungi $[9,10,32]$; yet, not all sensitized individuals will develop allergic symptoms [5]. Prevalence varies with age $[33,34]$ and can differ between countries [35]. Surveys based on skin prick testing (SPT), which is relatively insensitive for some fungal allergens, may underestimate the prevalence of IgE sensitization.

Type IV hypersensitivity reactions (delayed-type) may also play a role in allergic fungal airway disease. Type IV responses are T cell-mediated and induce apoptosis of target 
cells [27]. Both type I and IV hypersensitivity responses are observed in ABPA [36,37].

Fungal allergens can be secreted, cytoplasmic, or structural proteins [24,38]. Based on known allergens, predicted allergens, and the results of IgE binding to phage libraries, it has been suggested that $0.5 \%$ to $1 \%$ of fungal proteins may be allergens [39]. Although more than 80 fungal genera have been associated with allergy [9], the World Health Organization (WHO) and the International Union of Immunological Societies (IUIS; www.allergen.org, October 2016) list only 111 allergens from 29 fungal species. The majority of allergenic proteins are proteases, glycosidases, and stress response proteins or result from protein synthesis/secretion and gluconeogenesis [40]. The allergen profile can differ between fungal spores and germinated hyphae, and germination increases the amount of detectable allergens [21].

A person can be cosensitized to multiple allergens [41]. The fungi most associated with fungal polysensitization are Aspergillus fumigatus, Cladosporium herbarum, Penicillium chrysogenum, and Saccharomyces cerevisiae, whilst monosensitization occurs most commonly in individuals sensitized to Alternaria alternata [42]. The extent to which polysensitization is due to cross-sensitization between fungal allergens as opposed to primary sensitization is unclear [43]. An argument for the latter would be that fungal sensitization is often associated with sensitization to other airborne allergens [42]. While a few allergens are unique, such as the major allergens from $A$ fumigatus (Asp f 1) and $A$ alternata (Alt a 1) [38], the same or very similar epitopes can be shared between different organisms, which can include selfantigens $[38,44]$. These epitopes often derive from proteins with similar functions produced by various species and are known as orthologs [39]. This has been observed between closely related species such as P chrysogenum and Penicillium citrinum and distantly related species such as Candida boidinii and A fumigatus [45-47]. Cross-reactivity between fungal allergens may result in false-positive results in sensitization tests and contribute to exacerbation of allergic symptoms in conditions such as ABPA. Nevertheless, the clinical significance of cross-reactivity between fungal allergens requires further investigation [38].

Another factor to consider with fungal polysensitization is genetic predisposition, as suggested by an Italian study, where $82.9 \%$ of children sensitized to fungus had a family history of fungal sensitization [48]. However, few studies have explored the genetic basis of fungal lung disease other than some that link human leukocyte antigen genotypes with ABPA $[49,50]$.

\section{Diagnosis of Fungal Allergy}

It is unclear how much exposure to fungi over which time frame is necessary to trigger sensitization. Similarly, the role of genetic factors and immunoregulatory elements has not been clearly defined, since not everyone becomes sensitized. In general, until a person is known to be allergic to a specific component, he/she has to go through a process of anamnesis and allergen-reactivity tests. The SPT is most commonly used for the diagnosis of sensitization. While not as sensitive as intradermal tests [51], it has a lower rate of false positives [31].
In addition, blood tests for specific IgE are available, with the immunoassay capture (ImmunoCAP) system being a commonly used platform [23].

In 2004 , extracts for 75 fungal species were available from 7 different US manufacturers [52]; however, none of these have been approved by the United States Food and Drug Administration [23]. Fungi are not usually included in a standard SPT or specific IgE test panel because of a low index of suspicion that they are clinically relevant. Individuals with fungal allergies are often not aware of fungi as a potential allergen source, since they are frequently cosensitized to other aeroallergens such as grass pollens, which peak at similar times. If included, the most commonly tested fungi are $A$ alternata and $C$ herbarum, which are recommended in European Community Respiratory Health Survey [35]. However, for a more complete understanding of fungal sensitization, the panel should also include A fumigatus, $P$ chrysogenum, Candida albicans, Malassezia species, Trichophyton species, and Saccharomyces cerevisiae [7,10]. Most sensitization assays are aimed at fungi within the Ascomycota, in particular conidia-producing anamorphs (asexual forms) and yeasts [9]. The prevalence of sensitization to basidiospores (sexual spores from the Basidiomycota) is thought to be similar, although it is not often tested for, and allergic reactions to ascospores (sexual spores from the Ascomycota) are understudied [9]. Non-Dikarya fungi such as Rhizopus and Mucor species have also been implicated in asthma [10]. However, the number of species described is far higher, and many potential allergens are not well characterized.

Discrepancies between SPT and specific IgE make it difficult to ascertain an individual's fungal sensitization profile. Studies comparing SPT and specific IgE are often discordant in both asthma [32] and rhinitis [53]. The SPT has a high negative predictive value, whilst the ImmunoCAP is more sensitive, so some authors suggest using both [32]. It is important to note that sensitization patterns change with age [54-56], suggesting that measurement of sensitization has to be repeated over time. A possible reason for the problem of discordance is the fact that fungal extracts are not standardized and differ between SPT and IgE testing. Extracts vary between companies and even between batches from the same company. The choice of the fungal strain, culture conditions, protein source (spores, hyphae or secreted proteins), and extraction protocols used can all influence the allergen content and antigenicity of fungal extracts $[9,52]$.

\section{Conditions Related to Fungal Allergy}

\section{Allergic Fungal Rhinitis and Allergic Fungal Rhinosinusitis}

The nose is a key portal of entry for fungi into the respiratory system, with the result that fungi are often detected in nasal mucus culture [57]. Up to $40 \%$ of the population has allergic rhinitis with symptoms such as sneezing or clear rhinorrhea, which results in sleeping problems and decreased quality of life.

Allergic fungal rhinosinusitis (AFRS) accounts for 5\%$10 \%$ of all cases of chronic rhinosinusitis in immunocompetent 
patients and is caused by fungal colonization of a sinus with impaired mucociliary clearance [40]. AFRS represents 6\%-9\% of all cases of chronic rhinosinusitis requiring surgery [58]. Only around $50 \%$ of AFRS patients are asthmatic [59]. AFRS is mostly associated with Aspergillus species, followed by Bipolaris, Curvularia, and Alternaria. Other fungi, such as Rhizomucor and Fusarium, have rarely been implicated [60,61]. AFRS was first observed in a patient diagnosed with ABPA in 1976 who had characteristic fungal mucus plugs (composed of a thick eosinophilic secretion) in the paranasal sinuses [62]. This is why AFRS is sometimes described as the upper airway version of ABPA, even though the conditions rarely co-occur $[63,64]$. AFRS causes nasal airway obstruction, unilateral chronic sinus infection, thick dark mucous rhinorrhea, impaired postnasal drainage, and facial pain and pressure, as well as orbital and facial distortion in advanced disease $[65,66]$. The major diagnostic criteria for AFRS are sensitization to several fungi and other allergens, nasal polyposis, abnormalities revealed by computed tomography, eosinophilic mucus, presence of fungi without tissue invasion, and positive fungal stain of sinus contents $[40,65,67]$. Other characteristics include paranasal sinus mucoceles, high-attenuation sinus contents, bone remodelling (sinuses, orbit, and skull base) [68], higher total $\operatorname{IgE}[59]$, and T cell-mediated eosinophilic inflammation [40]. The underlying immune response of AFRS involves type I and IgG-mediated type III and type IV hypersensitivity responses, leading to impaired drainage of mucus through the sinonasal passages and subsequent fungal growth and inflammation.

\section{Asthma}

Asthma is a chronic disease that affects $>300$ million people worldwide [69]. It represents a large burden for health systems, with $£ 500$ billion per year being spent in the UK alone [70]. Patients experience variable airflow obstruction and a range of symptoms including breathlessness, airway inflammation, and reduced expiratory volume in 1 second $\left(\mathrm{FEV}_{1}\right)$ [69]. The symptoms are the result of pathophysiological abnormalities, including changes in the resistance to airflow and airway hypersensitivity responses of the airway smooth muscle cells, leading to contraction [71], increased cough reflex, mucus hypersecretion, and lung damage, which is expressed as fixed airflow obstruction, bronchiectasis, lung fibrosis [7,72], subepithelial membrane thickening, and smooth muscle hypertrophy and hyperplasia [73-75]. These abnormalities are independent of each other, thus resulting in a highly heterogeneous disease. Consequently, various endotypes, including allergic asthma, have been defined [76,77].

Several studies in both pediatric and adult populations have associated outdoor and indoor fungal exposure with asthma requiring hospital admission [78-81], decreased lung function, increased use of asthma medication, and greater risk of cough [82-89].

IgE-mediated fungal sensitization is frequently present in early-onset atopic eosinophilic asthma [7]. Sensitization to fungi, particularly Alternaria species, has been associated with life-threatening acute asthma attacks [90] and asthmarelated deaths [91], and fungi have been considered to cause asthma [92-94].
Severe asthma is present in 5\%-10\% of asthmatics, which means that patients require high doses of medication to treat their symptoms or experience symptoms despite optimal treatment [95]. Fungal exposure has been associated with asthma severity [96]. Almost $40 \%$ of children with asthma are sensitized to fungi, and prevalence is as high as $60 \%$ in children with severe asthma [97], which may persist into adulthood. The prevalence of fungal sensitization in adults with severe asthma can reach $70 \%$ [98], although it can be as high as $76 \%$ in those requiring multiple hospital admissions [96]. Patients with severe asthma are also more commonly cosensitized to multiple fungi [32]. People with moderate to severe asthma who are sensitized to Aspergillus have impaired lung function, as shown by reduced $\mathrm{FEV}_{1}$, more severe airway obstruction, and the need for higher corticosteroid doses $[99,100]$. A 22\% reduction in lung function was associated with fungal sensitization and fungus-positive sputum culture in patients with moderate to severe asthma [101]. The majority of recovered fungi were isolates of A fumigatus, although more than 20 other taxa were also detected [101]. Tissue damage and inflammation were also more frequent in Aspergillus-sensitized asthmatics, as more cases of bronchiectasis and higher eosinophil counts and IgE levels have been detected $[99,100]$. Culture of Aspergillus was significantly more frequent in patients with moderate-tosevere asthma who were IgE-sensitized to A fumigatus (63\%) than nonsensitized asthmatics (31\%) and healthy controls (7\%) [100]. These studies indicate that fungal colonization plays a role as a continuous allergic stimulus.

A fumigatus is by far the most common thermotolerant fungus associated with all forms of fungal lung disease, although other Aspergillus species such as A niger, A flavus, and $A$ nidulans can also play a role [102]. Besides Aspergillus species, C albicans, Bipolaris species, Schizophyllum commune, Curvularia species, and Pseudallescheria boydii have been involved in asthma, although most results are from case reports where disease was confirmed by culture. A convincing case for a causal association is not always made. Clinically relevant fungal allergy is usually present alongside other respiratory diseases such as cystic fibrosis (CF) and asthma, but can occur in their absence [31].

Evidence of fungal allergy complicating airway disease is found in about $7-9 \%$ of CF patients [10] and $0.7 \%-3.5 \%$ of patients with asthma [103]; however, these findings depend on the criteria used (see below). Fungal allergy plays a significant role in more than a quarter of patients with severe asthma. Fungal allergy was defined as an endotype of asthma by an EAACI Task Force [77].

\section{The Semantics of Fungal Allergy- Associated Airway Disease}

The term allergic bronchopulmonary aspergillosisABPA, or allergic bronchopulmonary mycosis when another fungal genus is involved, has dominated both the literature and conceptual approaches to fungal allergy in relation to asthma and CF. The term was first coined in the 1950s in a small case series describing a pattern of severe lung damage associated with fungal sensitization [104]. Further case series, mainly from the UK and USA, were published in subsequent decades, 
culminating in the 1970s in a description of the immunological and radiological features that characterized these patients, such as eosinophilia, fleeting lung shadows, bronchiectasis, high total $\operatorname{IgE}$, and raised $A$ fumigatus-specific $\operatorname{IgE}$ and IgG. These features became established in the literature as a firm set of diagnostic criteria. However, these criteria were based on a relatively small number of patients and lacked the statistical underpinning that would be expected in modern practice. The problem with the criteria is that they are largely based on a florid immune response to fungal sensitization characterized by high levels of total $\operatorname{IgE}$ and specific IgG. An IgE of $>417$ IU/L (or $1000 \mathrm{IU} / \mathrm{L}$ in some reports) is given great prominence $[7,105]$. However, total $\operatorname{IgE}$ is not a very specific or sensitive marker of fungal associated lung disease. While levels of IgE of $>1000 \mathrm{IU} / \mathrm{L}$ almost invariably denote the presence of $\operatorname{IgE}$ sensitization to thermotolerant fungi, they can also be due to yeasts such as Candida or skin commensals such as Malassezia or Trichophyton. Such sensitization is common, particularly if there is a history of eczema, which often accompanies asthma. Even where the raised $\operatorname{IgE}$ is due to Aspergillus or Penicillium sensitization, patients may have normal lung function with little evidence of the lung damage that is the hallmark of allergy to thermotolerant fungi. In addition, many patients with an IgE of $<417$ IU/L who are sensitized to fungi do have evidence of lung damage. The restrictive nature of the criteria for ABPA has meant that they do not make much sense to the practicing clinician, and, as a result, the term ABPA has tended to be used rather loosely to describe asthma where the clinician believes fungal allergy may be playing a part. As a result, the term has lost clarity if not credibility. A number of attempts have been made to revise the criteria over subsequent decades, but the problem is an element of circularity where the criteria for ABPA have been used as the gold standard starting point for revision [105]. An alternative approach was taken by the group in Manchester, who recognized the problem of placing considerable emphasis on total IgE and using the term severe asthma with fungal sensitization to refer to anyone with severe asthma and $\operatorname{IgE}$ sensitization to any fungi with an IgE concentration of less than $1000 \mathrm{IU} / \mathrm{L}$ [32]. However, again, this definition was based on the arbitrary cutoff of $1000 \mathrm{IU} / \mathrm{L}$, which is problematic in a condition where total $\mathrm{IgE}$ varies considerably over time. In addition, it includes people who are sensitized to nonthermotolerant fungi and yeasts, which are not obviously associated with lung damage in the same way as thermotolerant filamentous fungi. Moreover, many patients with fungal lung disease do not necessarily have asthma as it is usually defined (fungal allergy has a heterogeneous presentation), and if they do have asthma, this may not fit the criteria for severe asthma. The starting point for any discussion about the clinical relevance of fungal allergy should be what distinguishes it from asthma without fungal allergy. The evidence points towards lung damage with fixed airflow obstruction, bronchiectasis, and other radiological abnormalities (eg, fleeting shadows, mucus plugging, and lung fibrosis) as being particular features of fungal allergy. The question then should be, what are the best biomarkers of the presence of lung damage? We studied a population of 431 patients with generally severe asthma enriched by patients with fungal allergy to determine the relationship between immunological markers of sensitization, lung function, and radiological abnormalities [106]. The best biomarker was positive specific IgE to A fumigatus or P chrysogenum. This was independent of atopy. Total IgE was associated with fleeting lung shadows (present in a fraction of patients) and tree-in-bud shadowing on the computed tomography scan, but no other features of lung damage. We concluded that total $\mathrm{IgE}$ was not helpful in determining who was at risk from developing lung damage due to fungal allergy. However, an unbiased cluster analysis revealed a small population $(\sim 10 \%)$ with a florid immune response to fungi and very high total IgE, poor lung function (postbronchodilator $\mathrm{FEV}_{1} 63 \%$ predicted), and high rates of bronchiectasis (80\%). This group all met the criteria for ABPA and, presumably, represent those patients from whom the concept of ABPA was derived. Nevertheless, equal numbers of patients who fitted the criteria for ABPA were found in the other clusters, thus emphasizing the difficulty of separating ABPA from the general population of people with allergic sensitization to fungi in any statistically meaningful way. The conclusion from this study was that the only useful biomarker for predicting risk of developing lung damage in asthma associated with fungal allergy is positive $\operatorname{IgE}$ to thermotolerant filamentous fungi [106]. While a small subgroup of patients with a florid immune response are at higher risk of developing lung damage, separating them from the much larger body of patients with fungal allergy by using the term ABPA makes it difficult to appreciate the full spectrum of fungal allergy-related lung disease. To describe patients with airway disease who are IgEsensitized to thermotolerant fungi mainly of the Aspergillus and Penicillium genera, we prefer the inclusive term allergic fungal airway disease (AFAD), which can be qualified in terms of severity and also the underlying condition (eg, asthma, CF) if appropriate [7].

\section{Treatment of Allergic Fungal Airway Disease}

Therapeutic strategies against AFAD include allergen avoidance, antifungal medications, surgery, and immunotherapy.

\section{Allergen Avoidance}

Allergen avoidance is difficult, as fungi are ubiquitous in nature. Avoidance is further complicated by a lack of allergenic thresholds for most fungi, the exception being Alternaria and Cladosporium, where 100 spores for Alternaria and 3000 spores for Cladosporium per cubic meter of air is known to evoke allergic symptoms [107]. These thresholds are frequently exceeded outdoors during the late summer and autumn. Gardening, particularly composting and collection of dead and rotting vegetation, is a potentially important source of high levels of fungal spores, and gardeners with fungal allergy should wear masks during these tasks. Various occupations such as industrial composting and farming also bring people into contact with high levels of fungal spores, and many such industries have avoidance strategies in place. The risk of fungal exposure within buildings can be avoided by moving from the building [108] or decreased by active interventions 
such as removing visible mold or water damaged materials and application of fungicides [109-113]. The effectiveness of these strategies remains controversial, and, as a result, general guidelines for mold avoidance have not yet been established.

\section{Asthma Treatment}

Many patients with AFAD have severe asthma requiring intensive treatment, usually at the top stages of the British Thoracic Society guidelines. Sometimes this involves frequent courses of high-dose oral corticosteroids or continuous oral corticosteroids. However, as a group, acute severe exacerbations are not a particularly prominent feature of AFAD, and periods of poor control tend to be more chronic, coming on over days and weeks rather than hours and often lasting for months. Because of the frequency of bronchiectasis, exacerbations may be caused by bacterial bronchitis, which can be stubborn to treat. Omalizumab has occasionally proven successful in patients with ABPA [114-116], although no clinical trials of this treatment have been performed specifically in patients with AFAD. In patients undergoing pulmonary rehabilitation of severe fixed airflow obstruction, a program of exercise, education, and support provided by clinically trained staff is appropriate.

\section{Antifungal Therapy}

The key difference between the management of asthma with and without fungal complications is the potential role of antifungal therapy. Since fungal airway colonization is thought to be the underlying trigger for AFAD, there is a strong rationale for treatment with antifungal agents. However, in both clinical practice and in the small number of controlled clinical trials that have addressed this question, the outcome of treatment is often disappointing. Four randomized-controlled trials have assessed antifungal treatment in asthma associated with AFAD. Three used itraconazole [117-119], the fourth used voriconazole [120]. Although the disease names and inclusion criteria were slightly different in each study, the patient population was essentially the same in all 4 . There was a modest benefit at best in the 3 itraconazole studies and no improvement with voriconazole. The benefits seen with itraconazole may well have been due to its corticosteroidenhancing effects [121], which are less prominent with voriconazole. The minor benefit of triazole antifungal agents may be due in part to the difficulty in eradicating the fungi from the airways owing to lack of penetration of the drug into the bronchial lumen [122,123]. In the EVITA3 study [120], 40\% of patients still had at least 1 positive sputum culture while taking voriconazole. In addition, rates of positive sputum culture returned to baseline values within 2 months of stopping the intervention. Triazoles are more likely to be effective when there is active infection. AFAD can manifest as fungal bronchitis in which there is production of large amounts of mucopurulent sputum with heavy growth of filamentous fungi. Relatively few patients with AFAD experience this problem, but it is these patients who anecdotally do well with antifungal therapy. Selection for treatment with antifungals therefore requires careful identification of patients with active bronchitis reflecting heavy fungal colonization, as shown by culture of airway secretions. As methods for sputum fungal culture are not standardized or quantified and often insensitive [124], fungal bronchitis is not well recognized or characterized. Fungal bronchitis, however, is a common problem in all airway diseases irrespective of $\mathrm{IgE}$ sensitization and often involves yeast as well as filamentous fungi.

Treatment strategies for AFRS were extensively reviewed by Ryan et al [65]. AFRS is usually treated with surgery to remove the polyps and eosinophilic mucin, clear the affected sinuses, and create access for topical intranasal medication. If the sinuses are not completely cleared, inflammation will continue and resistance to anti-inflammatory drugs develops. Patients can take nasal irrigations and intranasal corticosteroids to reduce inflammation and maintain sinus drainage. AFRS patients, who were followed for 7 years, had to undergo an additional 2 surgeries and repeated courses of oral corticosteroids (yearly, on average), thereby showing persistent polypoid mucosal edema and increased total IgE. The advantage of antifungal treatment with itraconazole has not been unambiguously demonstrated. While itraconazole improved endoscopic appearance and reduced the use of oral corticosteroids and the frequency of the relapse phase $(30 \%)$ in some studies, it was noneffective or even worsened the conditions in $63 \%$ of AFRS patients [65]. Local treatment with fluconazole nasal spray was beneficial, resulting in the lowest recurrence rate $(10 \%)$, whereas a recurrence rate of $66.7 \%$ was recorded in patients receiving itraconazole. However, the clinical benefit of antifungal treatment requires further investigation.

\section{Immunotherapy}

Immunotherapy can cure allergic diseases, relieve symptoms, and reduce medication usage. The WHO guidelines for safe and effective immunotherapy recommend the use of well-defined vaccines for carefully selected patients [125]. However, fungal extracts are not standardized [9,52], and immunotherapy is not recommended for patients with asthma, since it very frequently leads to adverse reactions [30]. In their review, Twaroch et al [30] found only a limited number of controlled immunotherapy trials, inconsistent results, and a small clinical benefit of $A$ alternata and $C$ herbarum extracts in patients with rhinoconjunctivitis and/or mold-induced asthma. Subcutaneous immunotherapy with $C$ herbarum extract resulted in decreased bronchial, conjunctival, and skin reactivity, as well as increased peak expiratory flow and decreased medication score. However, symptoms were not significantly different between the treatment and placebo groups. Similar results were obtained with subcutaneous or sublingual immunotherapy using extracts from Alternaria species. An increase in IgG levels (including IgG4), which is generally considered favorable in immunotherapy, was common. Production of IgE probably derives from the activation of regulatory $\mathrm{T}$ cells (Treg), which is crucial for tolerance. The noninflammatory isotope is thought to prevent antigen-binding of $\mathrm{IgE}$ and therefore subsequent mast cell and basophil activation. Owing to its poor binding property, serum level itself is not an indicator of its protective function; similarly, a decrease in IgE levels is not an indicator of a decreased response to allergens. Instead, it is more likely that the $\mathrm{IgE} / \mathrm{IgG}$ ratio in serum shows a predominance of Tregs over $\mathrm{T}_{\mathrm{H}} 2$ cells [126]. 
The use of recombinant fungal allergens in immunotherapy has not yet been assessed, although hypoallergenic derivatives of Asp f 2 [127] and Alt a 1 were shown to efficiently block IgE binding in sera of fungus-sensitized patients [128]. Similar results were obtained with mutated Alt a 13 allergen, which also resulted in reduced IL-4 production by T cells and by Alt a 13treated peripheral blood mononuclear cells [129]. These studies are a good basis for further clinical trials using recombinant allergens, although more clinically relevant allergens need to be evaluated in the population before widespread use of vaccines can be implemented [30].

\section{Conclusion}

IgE sensitization to fungi is common in asthma, particularly in its more severe manifestations, affecting both children and adults. The clinical outcomes of allergy to aeroallergens such as Alternaria and Cladosporium are predictable from their spore levels and cause short-term allergic manifestations similar to those induced by grass pollen. The clinical impact is relatively modest considering the very high levels of spores in the summer and autumn, possibly because the spore envelope is relatively nonallergenic and the spores in some cases are too large to access the lower airways. Certain climatic conditions such as summer thunderstorms disrupt spores, rendering them more potent. In contrast, thermotolerant fungi such as Aspergillus and Penicillium species can colonize the lung, where they create more persistent allergenic stimuli and, when colonization is considerable, an infective component. This leads to progressive lung damage due in part to chronic obstruction of the airways with viscid mucus. All asthmatics who are IgE-sensitized to these fungi are at risk of developing lung damage, although a subset with a florid immune response are at the greatest risk. Present knowledge reveals no criteria other than $\operatorname{IgE}$ sensitization to thermotolerant filamentous fungi for selection of this or any other subgroup in a clinically useful way. Therefore, we prefer an inclusive term such as AFAD to identify asthmatics at risk from fungal allergy, as opposed to terms such as ABPA or severe asthma with fungal sensitization, which exclude significant numbers of relevant patients. Treatment of AFAD is similar to that of severe asthma, with the exception that triazole antifungals have a place in the treatment of accompanying fungal bronchitis.

\section{Acknowledgments}

The views expressed are those of the author(s) and not necessarily those of the NHS, the NIHR, or the Department of Health.

\section{Funding}

The research presented in this review was supported by the National Institute for Health Research (NIHR) Leicester Respiratory Biomedical Research Unit. The review presents independent research funded by the National Institute for Health Research (NIHR). Support was also received from Asthma UK and the Midlands Asthma and Allergy Research Association (MAARA).

\section{Conflicts of Interest}

Professor Wardlaw has received funding from Pfizer for a clinical trial in fungal allergy, from GSK for advisory work on fungal allergy, and from Pulmocide for advisory work on fungal allergy. Dr Pashley has received funding for advisory work from Pulmocide.

\section{References}

1. Kirk PM, Cannon PF, Minter DW, Stalpers JA. Ainsworth and Bisby's dictionary of the Fungi. 10th edition ed. Wallingford, UK: CAB International 2008.

2. Hawksworth DL. The magnitude of fungal diversity: the 1.5 million species estimate revisited. Mycol Res. 2001;105:142232.

3. Hawksworth DL. Global species numbers of fungi: are tropical studies and molecular approaches contributing to a more robust estimate? Biodivers Conserv. 2012;21(9):2425-33.

4. James TY, Kauff $F$, Schoch $C L$, Matheny PB, Hofstetter V, Cox CJ, Celio G, Gueidan C, Fraker E, Miadlikowska J, Lumbsch HT, Rauhut A, Reeb V, Arnold AE, Amtoft A, Stajich JE, Hosaka $K$, Sung GH, Johnson D, O'Rourke B, Crockett $M$, Binder $M$, Curtis JM, Slot JC, Wang Z, Wilson AW, Schussler A, Longcore JE, O'Donnell K, Mozley-Standridge S, Porter D, Letcher PM, Powell MJ, Taylor JW, White MM, Griffith GW, Davies DR, Humber RA, Morton JB, Sugiyama J, Rossman AY, Rogers JD, Pfister DH, Hewitt D, Hansen K, Hambleton S, Shoemaker RA, Kohlmeyer J, Volkmann-Kohlmeyer B, Spotts RA, Serdani $M$, Crous PW, Hughes KW, Matsuura K, Langer $E$, Langer $G$, Untereiner WA, Lucking $R$, Budel B, Geiser DM, Aptroot A, Diederich P, Schmitt I, Schultz M, Yahr R, Hibbett DS, Lutzoni F, McLaughlin DJ, Spatafora JW, Vilgalys R. Reconstructing the early evolution of Fungi using a six-gene phylogeny. Nature. 2006;443(7113):818-22.

5. Hardin BD, Kelman BJ, Saxon A. Adverse human health effects associated with molds in the indoor environment. Int J Occup Environ Med. 2003;45(5):470-78.

6. Hawksworth DL. The fungal dimension of biodiversity magnitude, significance, and conservation. Mycol Res. 1991;95:641-55.

7. Woolnough K, Fairs A, Pashley $\mathrm{CH}$, Wardlaw AJ. Allergic fungal airway disease: pathophysiologic and diagnostic considerations. Curr Opin Pulm Med. 2015;21(1):39-47.

8. Heitman J. Microbial Pathogens in the Fungal Kingdom. Fungal Biol Rev. 2011;25(1):48-60.

9. Horner WE, Helbling A, Salvaggio JE, Lehrer SB. Fungal Allergens. Clin Microbiol Rev. 1995;8(2):161-79.

10. Knutsen AP, Bush RK, Demain JG, Denning DW, Dixit A, Fairs A, Greenberger PA, Kariuki B, Kita H, Kurup VP, Moss RB, Niven RM, Pashley CH, Slavin RG, Vijay HM, Wardlaw AJ. Fungi and allergic lower respiratory tract diseases. J Allergy Clin Immunol. 2012;129(2):280-91.

11. Luong A, Marple BF. Update on Allergic Fungal Rhinosinusitis. Curr. Fungal Infect. Rep. 2007;1(1):12-18.

12. AllergyUK. Indoor allergy week 2011: The rise of 'home fever'. 2011.

13. Gupta R, Sheikh A, Strachan DP, Anderson HR. Burden of allergic disease in the UK: secondary analyses of national databases. Clin Exp Allergy. 2004;34(4):520-26. 
14. Pashley CH, Fairs A, Free RC, Wardlaw AJ. DNA analysis of outdoor air reveals a high degree of fungal diversity, temporal variability, and genera not seen by spore morphology. Fungal Biol. 2012;116(2):214-24.

15. Fairs A, Wardlaw AJ, Thompson JR, Pashley CH. Guidelines on ambient intramural airborne fungal spores. J Investig Allergol Clin Immunol. 2010;20(6):490-98.

16. Burge HA. An update on pollen and fungal spore aerobiology. J Allergy Clin Immunol. 2002;110(4):544-52.

17. Green BJ, Sercombe JK, Tovey ER. Fungal fragments and undocumented conidia function as new aeroallergen sources. J Allergy Clin Immunol. 2005;115(5):1043-8.

18. Green BJ, Tovey ER, Sercombe JK, Blachere FM, Beezhold DH, Schmechel D. Airborne fungal fragments and allergenicity. Med Mycol. 2006;44:S245-S55.

19. Cho SH, Seo SC, Schmechel D, Grinshpun SA, Reponen T. Aerodynamic characteristics and respiratory deposition of fungal fragments. Atmos Environ. 2005;39(30):5454-65.

20. Romani L. Immunity to fungal infections. Nat Rev Immunol. 2011;11(4):275-88

21. Green BJ, Mitakakis TZ, Tovey ER. Allergen detection from 11 fungal species before and after germination. J Allergy Clin Immunol. 2003;111(2):285-9.

22. Aimanianda V, Bayry J, Bozza S, Kniemeyer O, Perruccio K, Elluru SR, Clavaud C, Paris S, Brakhage AA, Kaveri SV, Romani L, Latge JP. Surface hydrophobin prevents immune recognition of airborne fungal spores. Nature. 2009;460(7259):1117-U79.

23. Crameri R, Garbani M, Rhyner C, Huitema C. Fungi: the neglected allergenic sources. Allergy. 2014;69(2):176-85.

24. Simon-Nobbe B, Denk U, Poll V, Rid R, Breitenbach M. The spectrum of fungal allergy. Int Arch Allergy Immunol. 2008;145(1):58-86.

25. Borghi $M$, Renga $G$, Puccetti $M$, Oikonomou V, Palmieri $M$, Galosi C, Bartoli A, Romani L. Antifungal Th immunity: growing up in family. Front Immunol. 2014;5:1-8.

26. Galli SJ, Tsai M, Piliponsky AM. The development of allergic inflammation. Nature. 2008;454(7203):445-54.

27. Rajan TV. The Gell-Coombs classification of hypersensitivity reactions: a re-interpretation. Trends Immunol. 2003;24(7): 376-9.

28. Wardlaw AJ, Woolnough K, Pashley CH. Lassoing a chimera: the semantics of allergic fungal airway disease. Clin Exp Allergy. 2015;45(12):1746-9.

29. Faergemann J. Atopic dermatitis and fungi. Clin Microbiol Rev. 2002;15(4):545-63.

30. Twaroch TE, Curin M, Valenta R, Swoboda I. Mold Allergens in Respiratory Allergy: From Structure to Therapy. Allergy Asthma Immunol Res. 2015;7(3):205-20.

31. Denning DW, Pashley C, Hartl D, Wardlaw A, Godet C, Del Giacco S, Delhaes L, Sergejeva S. Fungal allergy in asthmastate of the art and research needs. Clin Transl Allergy. 2014:4:14.

32. O'Driscoll BR, Powell G, Chew F, Niven RM, Miles JF, Vyas A, Denning DW. Comparison of skin prick tests with specific serum immunoglobin $E$ in the diagnosis of fungal sensitization in patients with severe asthma. Clin Exp Allergy. 2009;39:167783.

33. Niemeijer NR, de Monchy JG. Age-dependency of sensitization to aero-allergens in asthmatics. Allergy. 1992;47(4 Pt 2):431-5.
34. Bartra J, Belmonte J, Torres-Rodriguez JM, Cistero-Bahima A Sensitization to Alternaria in patients with respiratory allergy. Front Biosci (Landmark Ed). 2009;14:3372-79.

35. Bousquet PJ, Hooper R, Kogevinas M, Jarvis D, Burney P. Number of allergens to be tested to assess allergenic sensitization in epidemiologic studies: results of the European Community Respiratory Health Survey I. Clin Exp Allergy. 2007;37(5):780-7.

36. Agarwal R. Allergic Bronchopulmonary Aspergillosis. Chest. 2009;135(3):805-26.

37. Chowdhary A, Agarwal K, Kathuria S, Gaur SN, Randhawa HS, Meis JF. Allergic bronchopulmonary mycosis due to fungi other than Aspergillus: a global overview. Crit Rev Microbiol. 2014;40(1):30-48.

38. Crameri R, Zeller S, Glaser AG, Vilhelmsson M, Rhyner C. Cross-reactivity among fungal allergens: a clinically relevant phenomenon? Mycoses. 2009;52(2):99-106.

39. Bowyer P, Fraczek M, Denning DW. Comparative genomics of fungal allergens and epitopes shows widespread distribution of closely related allergen and epitope orthologues. BMC Genomics. 2006;7(1):251.

40. Vacher $G$, Niculita-Hirzel $H$, Roger $T$. Immune responses to airborne fungi and non-invasive airway diseases. Semin Immunopathol. 2014;37(2):83-96

41. Migueres M, Davila I, Frati F, Azpeitia A, Jeanpetit Y, LheritierBarrand M, Incorvaia C, Ciprandi G. Types of sensitization to aeroallergens: definitions, prevalences and impact on the diagnosis and treatment of allergic respiratory disease. Clin Transl Allergy. 2014;4:16.

42. Mari A, Schneider P, Wally V, Breitenbach M, Simon-Nobbe B. Sensitization to fungi: epidemiology, comparative skin tests, and IgE reactivity of fungal extracts. Clin Exp Allergy. 2003;33(10):1429-38.

43. Crameri R. The problem of cross-reactivity in the diagnosis of fungal allergy. Clin Exp Allergy. 2011;41(3):302-4.

44. Crameri R. Immunoglobulin E-binding autoantigens: biochemical characterization and clinical relevance. Clin Exp Allergy. 2012;42(3):343-51.

45. Hemmann S, Blaser K, Crameri R. Allergens of Aspergillus fumigatus and Candida boidinii share lgE-binding epitopes. Am J Respir Crit Care Med. 1997;156(6):1956-62.

46. Soeria-Atmadja $D$, Onell $A$, Borga $A$. IgE sensitization to fungi mirrors fungal phylogenetic systematics. J Allergy Clin Immunol. 2010;125(6):1379-86.

47. Shen HD, LinWL, Tsai JJ, Liaw SF, Han SH. Allergenic components in three different species of Penicillium: crossreactivity among major allergens. Clin Exp Allergy. 1996;26(4):444-51.

48. Cantani A, Ciaschi V. Epidemiology of Alternaria alternata allergy: a prospective study in 6840 Italian asthmatic children. Eur Rev Med Pharmacol Sci. 2004;8(6):289-94.

49. Chauhan B, Santiago L, Hutcheson PS, Schwartz HJ, Spitznagel E, Castro M, Slavin RG. Evidence for the involvement of two different MHC class II regions in susceptibility or protection in allergic bronchopulmonary aspergillosis. J Allergy Clin Immunol. 2000;106(4):723-9.

50. Chauhan B, Santiago L, Kirschmann DA, Hauptfeld V, Knutsen AP, Hutcheson PS, Woulfe SL, Slavin RG, Schwartz HJ, Bellone CJ. The association of HLA-DR alleles and T cell activation with allergic bronchopulmonary aspergillosis. J Immunol. 1997;159(8):4072-6. 
51. Agarwal R, Aggarwal AN, Gupta D, Jindal SK. Aspergillus hypersensitivity and allergic bronchopulmonary aspergillosis in patients with bronchial asthma: systematic review and meta-analysis. Int J Tuberc Lung Dis. 2009;13(8):936-44.

52. Esch RE. Manufacturing and standardizing fungal allergen products. J Allergy Clin Immunol. 2004;113(2):210-5.

53. Liang KL, Su MC, Jiang RS. Comparison of the skin test and ImmunoCAP system in the evaluation of mold allergy. J Chin Med Assoc. 2006;69(1):3-6.

54. Silvestri M, Rossi GA, Cozzani S, Pulvirenti G, Fasce L. Agedependent tendency to become sensitized to other classes of aeroallergens in atopic asthmatic children. Ann Allergy Asthma Immunol. 1999:83(4):335-40.

55. Malling HJ. Reproducibility of skin sensitivity using a quantitative skin prick test. Allergy. 1985;40(6):400-4.

56. Thomsen GF, Schlunssen V, Skadhauge LR, Malling TH, Sherson $\mathrm{DL}$, Omland $\mathrm{O}$, Sigsgaard T. Are allergen batch differences and the use of double skin prick test important? BMC Pulm Med. 2015;15:33.

57. Buzina W, Braun H, Freudenschuss K, Lackner A, Habermann W, Stammberger $H$. Fungal biodiversity - as found in nasal mucus. Med Mycol. 2003:41(2):149-61.

58. Bakhshaee M, Fereidouni M, Mohajer MN, Majidi MR, Azad FJ, Moghiman T. The prevalence of allergic fungal rhinosinusitis in sinonasal polyposis. Eur Arch Otorhinolaryngol. 2013;270(12):3095-8.

59. Marple BF. Allergic fungal rhinosinusitis: current theories and management strategies. Laryngoscope. 2001;111(6):100619.

60. Manning SC, Holman M. Further evidence for allergic pathophysiology in allergic fungal sinusitis. Laryngoscope. 1998;108(10):1485-96.

61. Montone KT, Livolsi VA, Feldman MD, Palmer J, Chiu AG, Lanza DC, Kennedy DW, Loevner LA, Nachamkin I. Fungal rhinosinusitis: a retrospective microbiologic and pathologic review of 400 patients at a single university medical center. Int J Otolaryngol. 2012;2012:684835.

62. Safirstein BH. Allergic bronchopulmonary aspergillosis with obstruction of the upper respiratory tract. Chest. 1976;70(6):788-90.

63. Greenberger PA. Allergic bronchopulmonary aspergillosis. J Allergy Clin Immunol. 2002;110(5):685-92.

64. Shah A, Panchal N, Agarwal AK. Concomitant allergic bronchopulmonary aspergillosis and allergic Aspergillus sinusitis: a review of an uncommon association. Clin Exp Allergy. 2001;31(12):1896-905.

65. Ryan MW, Clark CM. Allergic Fungal Rhinosinusitis and the unified airway: the role of antifungal therapy in AFRS. Curr Allergy Asthma Rep. 2015:15(12):75.

66. Callejas CA, Douglas RG. Fungal rhinosinusitis: what every allergist should know. Clin Exp Allergy. 2013;43(8):835-49.

67. Glass D, Amedee RG. Allergic fungal rhinosinusitis: a review. Ochsner J. 2011;11(3):271-5.

68. Ferguson BJ. Eosinophilic mucin rhinosinusitis: a distinct clinicopathological entity. Laryngoscope. 2000;110(5 Pt 1):799-813.

69. Bateman ED, Hurd SS, Barnes PJ, Bousquet J, Drazen JM, FitzGerald M, Gibson P, Ohta K, O'Byrne P, Pedersen SE, Pizzichini E, Sullivan SD, Wenzel SE, Zar HJ. Global strategy for asthma management and prevention: GINA executive summary. Eur Respir J. 2008;31(1):143-78.

70. Niven R. Asthma and mould allergy - Does it matter? Med Mycol. 2006;44:S257-S59.

71. Hargreave FE, Nair P. The definition and diagnosis of asthma. Clin Exp Allergy. 2009;39(11):1652-8.

72. Pavord ID, Wardlaw AJ. The A to E of airway disease. Clin Exp Allergy. 2010;40(1):62-7.

73. Wardlaw AJ, Brightling CE, Green R, Woltmann G, Bradding $P$, Pavord ID. New insights into the relationship between airway inflammation and asthma. Clin Sci. 2002;103(2):201-11.

74. Kay AB. Pathology of mild, severe, and fatal asthma. Am J Respir Crit Care Med. 1996;154(2):S66-S9.

75. Munakata M. Airway remodeling and airway smooth muscle in asthma. Allergol Int. 2006;55:235-43.

76. Edwards MR, Bartlett NW, Hussell T, Openshaw P, Johnston SL. The microbiology of asthma. Nat Rev Microbiol. 2012;10(7):459-71.

77. Lotvall J, Akdis CA, Bacharier LB, Bjermer L, Casale TB, Custovic A, Lemanske RF, Wardlaw AJ, Wenzel SE, Greenberger PA. Asthma endotypes: A new approach to classification of disease entities within the asthma syndrome. J Allergy Clin Immunol. 2011;127(2):355-60.

78. Atkinson RW, Strachan DP, Anderson HR, Hajat S, Emberlin J. Temporal associations between daily counts of fungal spores and asthma exacerbations. Int J Occup Environ Med. 2006:63(9):580-90.

79. Newson R, Strachan D, Corden J, Millington W. Fungal and other spore counts as predictors of admissions for asthma in the Trent region. Int J Occup Environ Med. 2000;57:786-92.

80. Dales RE, Cakmak S, Judek S, Dann T, Coates F, Brook JR, Burnett RT. The role of fungal spores in thunderstorm asthma. Chest. 2003;123(3):745-50.

81. Pulimood TB, Corden JM, Bryden C, Sharpies L, Nasser SM. Epidemic asthma and the role of the fungal mold Alternaria alternata. J Allergy Clin Immunol. 2007;120:610-7.

82. Delfino RJ, Zeiger RS, Seltzer JM, Street DH, Matteucci RM, Anderson PR, Koutrakis P. The effect of outdoor fungal spore concentrations on daily asthma severity. Environ Health Perspect. 1997;105(6):622-35.

83. Garrett MH, Rayment PR, Hooper MA, Abramson MJ, Hooper BM. Indoor airborne fungal spores, house dampness and associations with environmental factors and respiratory health in children. Clin Exp Allergy. 1998;28(4):459-67.

84. Andriessen JW, Brunekreef B, Roemer W. Home dampness and respiratory health status in European children. Clin Exp Allergy. 1998;28(10):1191-200.

85. ten Have WHo, van den Berg NJ, van der Palen J, van Aalderen WMC, Bindels PJE. Residential exposure to mould and dampness is associated with adverse respiratory health. Clin Exp Allergy. 2007;37(12):1827-32.

86. Meng J, Barnes CS, Rosenwasser LJ, Childrens Mercy Ctr Environm $\mathrm{H}$. Identity of the fungal species present in the homes of asthmatic children. Clin Exp Allergy. 2012;42(10):1448-58.

87. Reponen T, Lockey J, Bernstein DI, Vesper SJ, Levin L, Hershey GKK, Zheng S, Ryan P, Grinshpun SA, Villareal M, LeMasters $\mathrm{G}$. Infant origins of childhood asthma associated with specific molds. J Allergy Clin Immunol. 2012;130(3):639-44.

88. Reponen $T$, Vesper $S$, Levin $L$, Johansson $E$, Ryan P, Burkle J, Grinshpun SA, Zheng S, Bernstein DI, Lockey J, Villareal M, 
Hershey GKK, LeMasters G. High environmental relative moldiness index during infancy as a predictor of asthma at 7 years of age. Ann Allergy Asthma Immunol. 2011;107(2):1206

89. Park J-H, Cox-Ganser JM, Kreiss K, White SK, Rao CY. Hydrophilic fungi and ergosterol associated with respiratory illness in a water-damaged building. Environ Health Perspect. 2008;116(1):45-50.

90. Black PN, Udy AA, Brodie SM. Sensitivity to fungal allergens is a risk factor for life-threatening asthma. Allergy. 2000;55(5):501-4.

91. O'Hollaren MT, Yunginger JW, Offord KP, Somers MJ, Oconnell EJ, Ballard DJ, Sachs MI. Exposure to an aeroallergen as a possible precipitating factor in respiratory arrest in youngpatients with asthma. N Engl J Med. 1991;324(6):359-63.

92. Jaakkola MS, leromnimon A, Jaakkola JJK. Are atopy and specific lgE to mites and molds important for adult asthma? J Allergy Clin Immunol. 2006;117(3):642-8.

93. Piipari R, Keskinen H. Agents causing occupational asthma in Finland in 1986-2002: Cow epithelium bypassed by moulds from moisture-damaged buildings. Clin Exp Allergy. 2005:35(12):1632-7.

94. McDonald JC, Keynes HL, Meredith SK. Reported incidence of occupational asthma in the United Kingdom, 1989-97. Int J Occup Environ Med. 2000;57(12):823-9.

95. Chung KF, Wenzel SE, Brozek JL, Bush A, Castro M, Sterk PJ, Adcock IM, Bateman ED, Bel EH, Bleecker ER, Boulet LP, Brightling C, Chanez P, Dahlen SE, Djukanovic R, Frey U, Gaga M, Gibson P, Hamid Q, Jajour NN, Mauad T, Sorkness RL, Teague WG. International ERS/ATS guidelines on definition, evaluation and treatment of severe asthma. Eur Respir J. 2014;43(2):343-73.

96. O'Driscoll BR, Hopkinson LC, Denning DW. Mold sensitization is common amongst patients with severe asthma requiring multiple hospital admissions. BMC Pulm Med. 2005;5:4.

97. Vicencio AG, Santiago MT, Tsirilakis K, Stone A, Worgall S, Foley EA, Bush D, Goldman DL. Fungal sensitization in childhood persistent asthma is associated with disease severity. Pediatr Pulmonol. 2014;49(1):8-14.

98. Denning DW, O'Driscoll BR, Hogaboam CM, Bowyer P, Niven RM. The link between fungi and severe asthma: a summary of the evidence. Eur Respir J. 2006;27(3):615-26.

99. Menzies D, Holmes L, McCumesky G, Prys-Picard C, Niven R. Aspergillus sensitization is associated with airflow limitation and bronchiectasis in severe asthma. Allergy. 2011;66(5):67985.

100. Fairs A, Agbetile J, Hargadon B, Bourne M, Monteiro WR, Brightling CE, Bradding P, Green RH, Mutalithas K, Desai D, Pavord ID, Wardlaw AJ, Pashley CH. IgE sensitization to Aspergillus fumigatus is associated with reduced lung function in asthma. Am J Respir Crit Care Med. 2010;182(11):1362-8.

101. Agbetile J, Fairs A, Desai D, Hargadon B, Bourne M, Mutalithas K, Edwards RE, Morley JP, Monteiro WR, Kulkarni NS, Green RH, Pavord ID, Bradding P, Brightling CE, Wardlaw AJ, Pashley $\mathrm{CH}$. Isolation of filamentous fungi from sputum in asthma is associated with reduced post-bronchodilator FEV1. Clin Exp Allergy. 2012;42(5):782-91.

102. Tillie-Leblond L, Tonnel A-B. Allergic bronchopulmonary aspergillosis. Allergy. 2005;60:1004-13.
103. Denning DW, Pleuvry A, Cole DC. Global burden of allergic bronchopulmonary aspergillosis with asthma and its complication chronic pulmonary aspergillosis in adults. Med Mycol. 2013;51(4):361-70.

104. Hinson KFW, Moon AJ, Plummer NS. Bronchopulmonary aspergillosis - a review and a report of 8 new cases. Thorax. 1952; 7(4):317-33

105. Agarwal R, Chakrabarti A, Shah A, Gupta D, Meis JF, Guleria R, Moss R, Denning DW, ISHAM ACA. Allergic bronchopulmonary aspergillosis: review of literature and proposal of new diagnostic and classification criteria. Clin Exp Allergy. 2013;43(8):850-73.

106. Woolnough KF, Richardson $M$, Newby $C$, Craner M, Bourne M, Monteiro W, Siddiqui S, Bradding P, Pashley $\mathrm{CH}$, Wardlaw AJ. The relationship between biomarkers of fungal allergy and lung damage in asthma. Clin Exp Allergy. 2016.

107. Gravesen S. Fungi as a cause of allergic disease. Allergy. 1979;34(3):135-54.

108. Sudakin DL. Toxigenic fungi in a water-damaged building: an intervention study. Am J Ind Med. 1998;34(2):183-90.

109. Burr ML, Matthews IP, Arthur RA, Watson HL, Gregory CJ, Dunstan FDJ, Palmer SR. Effects on patients with asthma of eradicating visible indoor mould: a randomised controlled trial. Thorax. 2007;62(9):767-72.

110. Rudblad S, Andersson K, Stridh G, Bodin L, Juto JE. Slowly decreasing mucosal hyperreactivity years after working in a school with moisture problems. Indoor Air. 2002;12(2):13844.

111. Shortt N, Rugkasa J. "The walls were so damp and cold" fuel poverty and ill health in Northern Ireland: results from a housing intervention. Health Place. 2007;13(1):99-110.

112. Ebbehoj NE, Hansen MO, Sigsgaard T, Larsen L. Buildingrelated symptoms and molds: a two-step intervention study. Indoor Air. 2002;12(4):273-7.

113. Jarvis JQ, Morey PR. Allergic respiratory disease and fungal remediation in a building in a subtropical climate. Appl Occup Environ Hyg. 2001;16(3):380-8.

114. Braunstahl GJ, Chen CW, Maykut R, Georgiou P, Peachey $G$, Bruce J. The expeRience registry: the 'real-world' effectiveness of omalizumab in allergic asthma. Respir Med. 2013;107(8):1141-51.

115. Kanu A, Patel K. Treatment of Allergic Bronchopulmonary Aspergillosis (ABPA) in CF With Anti-lgE Antibody (Omalizumab). Pediatr Pulmonol. 2008;43:1249-51.

116. van der Ent CK, Hoekstra H, Rijkers GT. Successful treatment of allergic bronchopulmonary aspergillosis with recombinant anti-IgE antibody. Thorax. 2007;62:276-7.

117. Wark PAB, Hensley MJ, Saltos N, Boyle MJ, Toneguzzi RC, Simpson JL, McElduff P, Gibson PG. Anti-inflammatory effect of itraconazole in stable allergic bronchopulmonary aspergillosis: a randomized controlled trial. J Allergy Clin Immunol. 2003:111(5):952-7.

118. Stevens DA, Schwartz HJ, Lee JY, Moskovitz BL, Jerome DC, Catanzaro A, Bamberger DM, Weinmann AJ, Tuazon AU, Judson MA, Platts-Mills TAE, DeGraff AC. A randomised trial of itraconazole in allergic bronchopulmonary aspergillosis. $\mathrm{N}$ Engl J Med. 2000;342:756-62.

119. Denning DW, O'Driscoll BR, Powell G, Chew F, Atherton GT, Vyas A, Miles J, Morris J, Niven RM. Randomized controlled 
trial of oral antifungal treatment for severe asthma with fungal sensitization: the Fungal Asthma Sensitization Trial (FAST) study. Am J Respir Crit Care Med. 2009;179(1):11-8.

120. Agbetile J, Bourne M, Fairs A, Hargadon B, Desai D, Broad C, Morley J, Bradding P, Brightling CE, Green RH, Haldar P, Pashley $\mathrm{CH}$, Pavord ID, Wardlaw AJ. Effectiveness of voriconazole in the treatment of Aspergillus fumigatus-associated asthma (EVITA3 study). J Allergy Clin Immunol. 2014;134(1):33-9.

121. Raaska K, Niemi M, Neuvonen M, Neuvonen PJ, Kivisto KT. Plasma concentrations of inhaled budesonide and its effects on plasma cortisol are increased by the cytochrome P4503A4 inhibitor itraconazole. Clin Pharmacol Ther. 2002;72(4):362-9.

122. Sermet-Gaudelus I, Lesne-Hulin A, Lenoir G, Singlas $E$, Berche $P$, Hennequin C. Sputum itraconazole concentrations in cystic fibrosis patients. Antimicrob Agents Chemother. 2001;45(6):1937-8.

123. Rodvold KA, Yoo L, George JM. Penetration of anti-infective agents into pulmonary epithelial lining fluid: focus on antifungal, antitubercular and miscellaneous anti-infective agents. Clin Pharmacokinet. 2011;50(11):689-704.

124. Pashley CH, Fairs A, Morley JP, Tailor S, Agbetile J, Bafadhel $M$, Brightling CE, Wardlaw AJ. Routine processing procedures for isolating filamentous fungi from respiratory sputum samples may underestimate fungal prevalence. Med Mycol. 2012;50(4):433-8.

125. Bousquet J, Lockey R, Malling HJ. Allergen immunotherapy: therapeutic vaccines for allergic diseases. A WHO position paper. J Allergy Clin Immunol. 1998;102(4 Pt 1):558-62.
126. Fujita H, Soyka MB,Akdis M,Akdis CA. Mechanisms of allergenspecific immunotherapy. Clin Transl Allergy. 2012;2(1):2.

127. Banerjee B, Greenberger PA, Fink JN, Kurup VP. Conformational and linear B-cell epitopes of Asp f 2, a major allergen of Aspergillus fumigatus, bind differently to immunoglobulin $E$ antibody in the sera of allergic bronchopulmonary aspergillosis patients. Infect Immun. 1999;67(5):2284-91.

128. Twaroch TE, Focke M, Fleischmann K, Balic N, Lupinek C, Blatt K, Ferrara R, Mari A, Ebner C, Valent P, Spitzauer S, Swoboda I, Valenta R. Carrier-bound Alt a 1 peptides without allergenic activity for vaccination against Alternaria alternata allergy. Clin Exp Allergy. 2012;42(6):966-75.

129. Shankar J, Singh BP, Gaur SN, Arora N. Engineered Alt a 13 fragment of Alternaria alternata abrogated lgE binding without affecting T-cell stimulation. J Clin Immunol. 2009;29(1):63-70.

\section{- Andrew Wardlaw}

Institute for Lung Health

Department of Infection, Immunity \& Inflammation, University of Leicester

Department of Respiratory Medicine, University Hospitals of Leicester NHS Trust

Leicester, LE1 9HN

UK

E-mail: aw24@le.ac.uk 